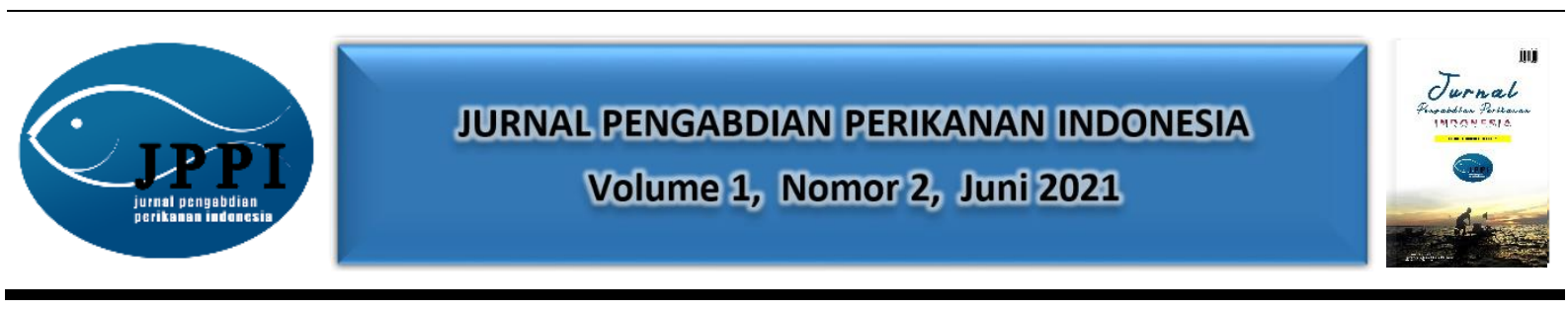

\title{
TINGKAT KELANGSUNGAN HIDUP DAN PERTUMBUHAN IKAN GABUS (Channa striata) YANG DIBERI PREBIOTIK MADU DAN JEROAN PATIN
}

\author{
Ricky Djauhari, Shinta S. Monalisa, Ivone Christiana \\ Program Studi Budidaya Perairan, Universitas Palangka Raya \\ Jalan Cik Ditiro Nomor 48, Kota Palangka Raya, Provinsi Kalteng \\ Alamat korespondensi : djrickyaku@gmail.com \\ (Tanggal Submission: 10 Juni 2021, Tanggal Accepted : 29 Juni 2021)
}

\begin{abstract}
Keyword: $\quad$ Abstrak:
Tingkat Penelitian ini bertujuan untuk mengetahui pengaruh suplementasi madu sebagai kelangsungan prebiotik dalam pakan komersial dan pakan berupa pasta jeroan ikan patin hidup, terhadap tingkat kelangsungan hidup dan pertumbuhan benih ikan gabus (Channa pertumbuhan, striata). Dalam penelitian ini, madu dicampurkan ke pakan dengan metode coated Channa striata, dengan dosis $0,6 \%$ (A) dan pasta jeroan ikan patin (B). Ikan dengan bobot tubuh prebiotik madu, awal 2,25-2,75 g dipelihara di tiga kolam dengan total 6 jaring hapa ukuran $1 \times 1 \times 1$ jeroan patin $\quad\left(\mathrm{m}^{3}\right)$ (20 ekor / jaring hapa), yaitu 2 jaring hapa ditempatkan di setiap kolam. Dengan demikian dapat terwakili setiap ulangan perlakuan di setiap kolam. Ikan diberi pakan perlakuan dengan tiga ulangan selama 28 hari. Tingkat kelangsungan hidup, laju pertumbuhan harian dan tingkat pertambahan bobot tubuh tertinggi didapatkan pada kelompok ikan gabus yang mengkonsumsi pakan berupa pasta jeroan patin, masing-masing sebesar $100 \%, 2,7 \%$ dan $130 \%$. Kelompok ikan gabus yang mengkonsumsi pakan komersial mengandung prebiotik madu menghasilkan tingkat kelangsungan hidup, laju pertumbuhan harian dan tingkat pertambahan bobot tubuh terendah, masing-masing sebesar $5 \%, 0,65 \%$ dan $20 \%$. Sifat kanibal ekstrem menjadi penyebab tingkat kelangsungan hidup paling rendah.
\end{abstract}

Panduan Sitasi (APPA $7^{\text {th }}$ edition) :

Djauhari, S., Monalisa, S.S., \& Christiana, I. (2021). Tingkat Kelangsungan Hidup Dan Pertumbuhan Ikan Gabus (Channa Striata) Yang Diberi Prebiotik Madu Dan Jeroan Patin. Jurnal Pengabdian Perikanan Indonesia, 1 (2), 88-97. http://doi.org/ 10.29303/jppi.v1i2.109

\section{PENDAHULUAN}

Budidaya ikan gabus (Channa striata) sudah mulai berkembang di Indonesia, namun terkendala tingkat mortalitas pada fase pemeliharaan benih masih tinggi, dikarenakan karakter kanibal yang dimiliki ikan gabus (Wicaksono et al., 2019; Rahmadya et al., 2015). Kendala lain yang dihadapi adalah mortalitas yang disebabkan oleh jenis pakan yang tidak 
sesuai (Curnow et al., 2006). Budidaya ikan gabus masih mengandalkan ketersediaan pakan berupa trash fish yang seringkali mengandung masalah krusial dalam aplikasinya, yaitu kualitas dan komposisi nutrisi trash fish yang bervariasi. Selain itu, risiko introduksi penyakit, polusi lingkungan dan tingginya nilai rasio konversi pakan. Oleh karena itu, berbagai upaya domestikasi ikan gabus dilakukan untuk akuakultur masa depan spesies ikan ini sangat prospektif terkait nilai ekonomis dan nutrisi penting yang tinggi, kandungan albumin karkas yang sangat bermanfaat untuk penyembuhan luka (Hidayati et al., 2017; Mustafa et al., 2012), serta pertumbuhannya relatif cepat di perairan rawa gambut, termasuk Provinsi Kalimantan Tengah.

Pemanfaatan limbah jeroan ikan patin telah lama dimanfaatkan, antara lain gelembung renang, usus, hati dan lemak sebagai bahan baku pakan ikan. Dari bobot ikan patin yang difilet dihasilkan lemak patin rata-rata sekitar $2,2 \%$ yang mengandung asam lemak $n-3$ dan $n-6$ masing-masing berkisar 7,02\% dan 6,68\%; keduanya sangat esensial bagi ikan air tawar pada umumnya. Untuk mengurangi biaya pakan dalam budidaya ikan yang relatif mahal, petani ikan berupaya membuat pakan sendiri, oleh karena itu jeroan ikan patin bisa menjadi solusi alternatif. (Jusadi et al., 2003; Setiawati et al., 2007).

Pemilihan selektif jenis pakan yang sesuai seringkali menjadi dilema, dikarenakan penggunaan bahan baku berkualitas sesuai kebutuhan nutrisi ikan gabus di satu sisi dapat mereduksi sifat kanibal, namun di sisi lain berpotensi memengaruhi feed intake dan tingkat kelangsungan hidup ikan. Salah satu solusi alternatif pendukung yang umum dilakukan untuk mitigasi kanibalisme pada ikan gabus adalah kegiatan menyortir.

Prebiotik adalah imuno polisakarida yang tidak dapat dicerna inang namun secara selektif memberi efek menguntungkan dengan merangsang pertumbuhan dan aktivitas metabolisme sejumlah bakteri menguntungkan di dalam usus, sehingga dapat memperbaiki keseimbangan dinamis populasi bakteri usus (Merrifield et al., 2010). Beberapa prebiotik akuakultur yang sudah diaplikasikan termasuk frukto oligosakarida (FOS), transgalakto oligosakarida (TOS), mannan oligosakarida (MOS), laktosa, inulin (Teitelbaum and Walker, 2002; Vulevic et al., 2004) dan madu. Hasil penelitian Djauhari et al. (2017) suplementasi ekstrak ubi jalar (Ipomoea batatas L.) dosis 2\% menghasilkan kinerja pertumbuhan, respons imun dan resistensi ikan mas (Cyprinus carpio) terhadap infeksi Aeromonas hydrophila melalui modifikasi dan pertumbuhan dominan lima spesies bakteri di usus ikan mas, yaitu Bacillus pumilus, Staphylococcus kloosii, Staphylococcus hominis, Aeromonas veronii dan Kocuria rhizophila. Suplementasi prebiotik inulin dosis $1,25 \mathrm{~g} / \mathrm{kg}$ pakan mampu memperbaiki rasio kalsium fosfor tubuh, menurunkan kadar glukosa darah dan meningkatkan kinerja pertumbuhan ikan betok (Anabas testudineus) (Siburian et al., 2020).

Salah satu sumber prebiotik alternatif yang dapat dimanfaatkan untuk kegiatan budidaya ikan adalah madu. Madu memiliki kriteria sebagai prebiotik karena tahan terhadap asam lambung dan enzim pencernaan, mampu menstimulasi pertumbuhan bakteri menguntungkan di usus ikan secara selektif (Karimah et al., 2011). Pemberian madu polen (ElAsely et al., 2014) dan propolis (Azza and Abd-El Rahman, 2009) dapat meningkatkan kinerja pertumbuhan, respons imun, dan resistansi ikan nila (Oreochromis niloticus) terhadap infeksi Aeromonas hydrophila. Pemberian prebiotik madu dosis $0,6 \%$ melalui pakan mampu meningkatkan kinerja pertumbuhan ikan bawal air tawar (Colossoma macropomum) (Silalahi et al., 2021). Namun, sejauh ini belum ada data tentang respons ikan gabus (Channa striata) yang diberi suplementasi pakan mengandung madu dan pakan berupa pasta jeroan ikan patin. Sebagaimana diketahui bahwa, tingkat kelangsungan hidup dan pertumbuhan 
merupakan parameter biologik yang paling menentukan berhasil atau gagalnya bisnis akuakultur, termasuk usaha budidaya ikan gabus. Oleh karena itu, penelitian ini dirancangkan bertujuan untuk mengetahui pengaruh pemberian prebiotik madu pada pakan dan pasta jeroan ikan patin terhadap pertumbuhan dan kelangsungan hidup ikan gabus (Channa striata).

\section{METODE PELAKSANAAN}

Penelitian dilaksanakan selama 28 hari pada Maret-April 2021 di UD. Airwana Raya, Jalan Anggrek Lingkar Luar, Kelurahan Kereng Bangkirai, Kecamatan Sebangau, Kota Palangka Raya, Kalimantan Tengah. Ikan uji yang digunakan yaitu ikan gabus (Channa striata) dengan bobot rata- rata 2,25-2,75 g (menggunakan timbangan Kenko model KK-SW1W kapasitas 30 $\mathrm{kg} \times 1 \mathrm{~g}$ ), diadaptasi selama 1 minggu. Penelitian ini menggunakan 3 kolam tanah, masingmasing dipasang 2 hapa. Pada kolam 1 ada A1 dan B3; di kolam 2 ada A2 dan B2; dan di kolam 3 ada $B 1$ dan $A 3$. Hapa yang digunakan berukuran $(1 \times 1 \times 1) \mathrm{m}^{3}$ dengan jumlah ikan yang ditebar sebanyak 20 ekor per hapa (Widodo et al. 2014).

Persiapan pakan uji dilakukan dengan menambahkan prebiotik madu komersial dengan dosis $0,6 \%$ (perlakuan A) $(\mathrm{v} / \mathrm{w})$ dan pasta jeroan ikan patin (perlakuan B). Pencampuran pakan komersial dengan kandungan protein sebesar $38 \%$ dan prebiotik madu dilakukan dengan menambahkan madu ke dalam pakan sesuai dosis perlakuan lalu ditambahkan phosphate buffered saline (PBS) dengan perbandingan 1:1 $(\mathrm{v} / \mathrm{v})$. Pencampuran madu dengan pakan buatan dilakukan dengan metode coating dan ditambahkan $2 \%$ putih telur sebagai binder (perekat). Selanjutnya pakan dikering udarakan selama kurang lebih 10 menit dan siap diberikan ke ikan uji. Sedangkan pembuatan pakan pasta dengan bahan baku jeroan ikan patin, digiling dan dikukus selama \pm 5 menit, kemudian dijadikan pasta. Setelah itu didinginkan lalu diberikan ke ikan berupa pasta (Kusuma, 2017). Pemberian pakan selama penelitian dilakukan secara at satiation dengan frekuensi 2 kali sehari (08.00 dan 16.00 WIB). Parameter eksperimen yang diukur meliputi tingkat kelangsungan hidup ikan (TKH), laju pertumbuhan harian (LPH), dan tingkat pertambahan bobot tubuh (Wg).

\section{HASIL KEGIATAN}

Berdasarkan hasil penelitian selama 28 hari diperoleh data pertumbuhan yang terdiri dari laju pertumbuhan harian (LPH), tingkat pertambahan bobot tubuh (Wg) dan tingkat kelangsungan hidup (TKH) (Tabel 1). TKH yang diperoleh untuk pemberian perlakuan prebiotik madu pada ikan gabus berkisar 5-100\%, sementara penggunaan pasta jeroan patin $85-100 \%$. Bobot rata-rata akhir ikan gabus berkisar antara 2,35 sampai $35 \mathrm{~g}$, laju pertumbuhan harian 0,65-2,97\% dan tingkat pertambahan bobot tubuh 20-130\%.

Tabel 1. Bobot tubuh awal (Wo), bobot tubuh akhir (Wt), biomassa awal (Bo), biomassa akhir $(B t)$, selisih biomassa akhir dan awal $(\Delta B)$, laju pertumbuhan harian $(L P H)$, tingkat pertambahan bobot tubuh $(\mathrm{Wg})$, dan tingkat kelangsungan hidup (TKH) benih ikan gabus (Channa striata) yang diberi pakan berupa pasta jeroan ikan patin dan suplementasi prebiotik madu dalam pakan komersial selama 28 hari pemeliharaan. 


\begin{tabular}{|c|c|c|c|c|c|c|c|c|c|}
\hline & $\begin{array}{c}\text { Parameter/ } \\
\text { Perlakuan }\end{array}$ & $\begin{array}{l}\text { Wo } \\
\text { (g) }\end{array}$ & $\begin{array}{l}\text { Wt } \\
\text { (g) }\end{array}$ & $\begin{array}{l}\text { Bo } \\
\text { (g) }\end{array}$ & $\begin{array}{l}\mathrm{Bt} \\
\text { (g) }\end{array}$ & $\begin{array}{l}\Delta \mathrm{B} \\
(\mathrm{g})\end{array}$ & $\begin{array}{l}\text { LPH } \\
\text { (\%) }\end{array}$ & $\begin{array}{l}W g \\
(\%)\end{array}$ & $\begin{array}{l}\text { TKH } \\
(\%)\end{array}$ \\
\hline \multirow{2}{*}{ Kolam 1} & A1 & 2,75 & 4,75 & 55 & 95 & 40 & 1,95 & 72,73 & 100 \\
\hline & B3 & 2,25 & 3,89 & 45 & 70 & 25 & 1,58 & 55,56 & 90 \\
\hline \multirow{2}{*}{ Kolam 2} & $A 2$ & 2,5 & 35 & 50 & 35 & - & - & - & 5 \\
\hline & B2 & 2,5 & 5,75 & 50 & 115 & 65 & 2,97 & 130 & 100 \\
\hline \multirow{2}{*}{ Kolam 3} & B1 & 2,5 & 2,35 & 50 & 40 & - & - & - & 85 \\
\hline & A3 & 2,5 & 3,16 & 50 & 60 & 10 & 0,65 & 20 & 95 \\
\hline
\end{tabular}

Parameter fisika kimia media air akuakultur memiliki peranan cukup penting antara lain suhu, $\mathrm{pH}$, dan kandungan oksigen terlarut. Pada Tabel 2 menunjukkan kisaran nilai parameter kualitas air tersebut selama 28 hari pemeliharaan benih ikan gabus. Ikan ini dikenal mampu bertahan pada kondisi lingkungan perairan yang kurang menguntungkan, tetapi akan tumbuh normal dan optimal pada perairan yang sesuai dengan persyaratan habitatnya.

Tabel 2. Kualitas air selama 28 hari pemeliharaan benih ikan gabus (Channa striata)

\begin{tabular}{ccccc}
\hline Parameter & Kolam 1 & Kolam 2 & Kolam 3 & Sumber ${ }^{*}$ ) \\
\hline Suhu $\left({ }^{\circ} \mathrm{C}\right)$ & $28,7-30,5$ & $28,5-30,8$ & $26,3-27,1$ & $25-32$ \\
$\mathrm{pH}$ & $6,3-6,8$ & $6,4-6,8$ & $6,1-6,3$ & $6,5-8,5$ \\
$\mathrm{DO}(\mathrm{mg} / \mathrm{L})$ & $4,5-5,7$ & $4,7-5,9$ & $3,9-4,1$ & $3-7$ \\
\hline
\end{tabular}

*) Kordi (2013)

Prebiotik adalah karbohidrat yang tidak tercerna oleh ikan, sebagian besar berupa monosakarida rantai pendek yang umumnya dikenal sebagai oligosakarida. Prebiotik merupakan komponen karbohidrat yang lepas dari metabolisme pencernaan tingkat tinggi pada saluran pencernaan, namun dapat mengubah komposisi mikroflora usus dengan cara mengubah tipe substrat yang lebih sesuai dengan kondisi mikroekofisiologi mikroflora usus residen spesifik, sehingga cepat berkembang. Oleh karena itu, efek prebiotik bersifat spesifik karakter, artinya prebiotik hanya meningkatkan pertumbuhan mikroflora menguntungkan dan atau mereduksi mikroflora patogen di dalam usus inang, mengurangi $\mathrm{pH}$ cairan usus melalui produksi asam-asam lemak rantai pendek (SCFA), dan mengubah konsentrasi enzim ekstraseluler yang dihasilkan oleh probiotik (Woods dan Gorbach, 2001; Gibson dan Roberfroid, 1995; Mei et al., 2011). Berbagai jenis komponen karbohidrat yang mempunyai karakteristik prebiotik dan telah banyak diaplikasikan pada sistem akuakultur adalah mannanoligosakarida (MOS), fruktooligosakarida (FOS), galaktooligosakarida (GOS), inulin, transgalaktooligosakarida (TOS) dan laktosa (Hoffmann 2012). Salah satu bahan alami yang dapat digunakan sebagai sumber prebiotik dan mengandung beberapa jenis oligosakarida seperti frukto oligosakarida (FOS), galakto oligosakarida (GOS), dan inulin adalah madu (Sanz et al. 2015). Prebiotik madu mengandung berbagai komponen oligosakarida, yaitu inulin sebesar 6,9\%, fruktooligosakarida (FOS) sebesar 39\% dan galaktooligosakarida (GOS) sebesar 31\% (Fuandila et al., 2019).

Hasil penelitian ini menunjukkan bahwa suplementasi madu diduga dapat meningkatkan populasi dan diversitas bakteri menguntungkan pada usus ikan uji. Pada perlakuan A2 menunjukkan tingkat mortalitas ikan mencapai 95\%, membuktikan bahwa ikan gabus memiliki karakter kanibal yang masih sangat menonjol, artinya proses fisiologi adaptasi tingkah laku makan belum sepenuhnya teradaptasi dari trash fish ke pakan komersial berupa pellet. Benih ikan gabus yang diberi pakan komersial dengan kandungan protein $32 \%$ dan ikan 
rucah menghasilkan tingkat kelangsungan hidup masing-masing sebesar 72,5\% dan $85 \%$ (Saputra et al., 2018). Apakah suplementasi madu mampu memicu agresivitas sifat kanibal ikan masih memerlukan konfirmasi penelitian selanjutnya yang lebih intensif. Peningkatan populasi dan diversitas bakteri probiotik di usus dipengaruhi oleh dosis prebiotik yang diberikan, jumlah total dan diversitas bakteri semakin meningkat seiring dengan meningkatnya dosis prebiotik madu yang diberikan. Hal tersebut mengindikasikan bahwa dosis prebiotik yang diberikan menyediakan substrat untuk pertumbuhan bakteri di dalam saluran pencernaan sehingga populasi dan diversitasnya lebih tinggi dibanding kontrol (Djauhari et al., 2017). Kenfack et al. (2018) berhasil mengisolasi 5 strain spesies bakteri probiotik Lactobacillus plantarum dari saluran pencernaan lebah madu, yang terkenal sebagai bakteri asam laktat (LAB) dan diklasifikasikan sebagai GRAS (generally recognized as safe).

Secara umum, nilai laju pertumbuhan harian dan tingkat pertambahan bobot tubuh terlihat lebih baik pada ikan gabus yang mengkonsumsi pakan berupa pasta jeroan patin. Hasil penelitian perlakuan B2 memperlihatkan nilai laju pertumbuhan harian, tingkat pertambahan bobot tubuh dan tingkat kelangsungan hidup ikan tertinggi dicapai pada kelompok ikan yang mengkonsumsi pakan berupa pasta jeroan patin. Asam lemak esensial yang terkandung dalam jeroan patin merupakan bagian dari fosfolipid yang terdapat pada membran sel. Sifat fisik dari membran sel ini ditentukan oleh fosfolipid yang ada pada membran, komposisi asam lemak pada fosfolipid serta interaksinya dengan kolesterol dan protein. Adanya asam lemak tak jenuh pada membran sel dapat memengaruhi sifat fluiditas membran dan memperbaiki fungsi membran (Bell et al., 1986). Selanjutnya fluiditas membran akan berpengaruh terhadap aktivitas enzim yang terdapat pada membran, seperti $\mathrm{Na}^{+} \mathrm{K}^{+}$ATPase (Hepher, 1988). Adanya peranan asam lemak esensial dapat memengaruhi metabolisme dalam sel sehingga komposisi asam lemak esensial yang tepat akan menghasilkan metabolisme sel yang optimal. Di sisi lain, penggunaan jeroan patin mampu meningkatkan komposisi asam lemak dokosaheksanat (DHA) di dalam daging ikan. Dengan kata lain, penggunaan jeroan patin diduga dapat memperbaiki kualitas daging ikan gabus dilihat dari kepentingan manusia yang mengkonsumsinya (Setiawati et al., 2007). Hal ini tentunya masih memerlukan penelitian lebih intensif terkait pencampuran jeroan patin dengan ikan rucah (trash fish) maupun pemberian pakan silih berganti dengan selang waktu tertentu antara pakan komersial berupa pellet dan pakan berupa pasta trash fish untuk budidaya ikan gabus. Meskipun demikian, perlakuan B1 justru menunjukkan hasil yang sebaliknya. Ikan gabus diduga memiliki kesanggupan memilih dan ingestion jenis pakan yang disukai; tingkah laku makan ini cenderung optimal saat pilihan jenis pakan yang disukai tersedia. Hal ini diduga terkait erat dengan adaptasi struktur morfologi, fisiologi dan fungsi enterosit. Laju pertumbuhan harian dan tingkat pertambahan bobot tubuh ikan gabus terendah terdapat pada kolam 3 , diperlihatkan oleh perlakuan $A 3$, dengan nilai masing-masing $0,65 \%$ dan $20 \%$. Hal ini menunjukkan bahwa pakan yang telah diberikan selama pemeliharaan sudah melebihi kebutuhan energi ikan untuk pemeliharaan tubuhnya (maintenance) sehingga selebihnya digunakan untuk pertumbuhan, meskipun dengan laju yang sangat rendah. Bahkan, pada perlakuan B1 ditemui pertumbuhan negatif. Abnormalitas pertumbuhan kelompok ikan perlakuan A3 dan B1 diduga disebabkan oleh kombinasi faktor internal, antara lain gangguan metabolisme dan imunodefisiensi, serta faktor eksternal terkait kelarutan oksigen yang rendah dan lambatnya kemampuan adaptasi benih ikan gabus terhadap lingkungan serta kemungkinan investasi ektoparasit maupun endoparasit selama masa pemeliharaan. 
Penggunaan pakan pellet komersial sebenarnya sudah populer diaplikasikan pada spesies ikan karnivora untuk mereduksi ketergantungan terhadap trash fish dan dampak lingkungan. Bahkan, menghasilkan laju pertumbuhan dan keuntungan yang lebih besar, seperti pada budidaya Lates calcarifer (Aquacop et al. 1989), Epinephelus fuscoguttatus (Rachmansyah et al., 2009), Lateolabrax japonicus dan Sciaenops ocellata (Cremer et al. 2001a,b). Sebagaimana diketahui bahwa pengatur utama fenotipe penting dalam akuakultur adalah tumbuh cepat, tahan penyakit, dan efisien dalam memanfaatkan pakan. Perbaikan performa pertumbuhan tersebut disebabkan oleh adanya aktivitas enzim pencernaan yang meningkat, perbaikan struktur mikrovilli pada permukaan enterosit yang membuat permukaan sel penyerap nutrien menjadi lebih luas sehingga efisiensi pakan meningkat, serta produksi asam lemak rantai pendek (SCFA) sebagai hasil fermentasi prebiotik oleh mikroflora endoseluler usus. Suplementasi MOS dengan dosis $0.2 \%$ meningkatkan panjang mikrovilli larva cobia (Rachycentron canadum) (Salze et al., 2008) dan peningkatan densitas mikrovilli usus bagian depan dan belakang gilthead sea bream (Sparus aurata) (Dimitroglou et al. 2010). Oligosakarida juga mampu memperbaiki morfologi usus seiring dengan potensi mengendalikan stres oksidatif, sehingga meningkatkan efisiensi kapasitas penyerapan usus melalui mekanisme perluasan area mikrovilli usus, yang berdampak positif terhadap pertumbuhan (Solis de los Santos et al. 2005; Song et al., 2010).

Suplementasi madu diduga mampu memodifikasi keberadaan probiotik di dalam saluran pencernaan yang dapat meningkatkan aktivitas enzim saluran pencernaan ikan gabus. Enzim amilase, protease, dan lipase yang dihasilkan probiotik dapat menyumbang aktivitas enzim endogenous ikan sehingga ikan yang mengkonsumsi pakan mengandung prebiotik secara tidak langsung memiliki aktivitas enzim pencernaan yang lebih tinggi. Peningkatan aktivitas enzim selanjutnya dapat membantu memperbaiki kecernaan pakan. Probiotik mampu membantu proses pencernaan sehingga pertumbuhan ikan lebih baik karena menghasilkan berbagai macam enzim ekstraseluler, antara lain amilase, protease dan lipase sehingga pencernaan pakan serta pemanfaatan nutrien menjadi lebih efisien (Djauhari et al., 2017). Enzim protease yang dihasilkan oleh probiotik berfungsi untuk membantu memecah ikatan-ikatan peptida dalam protein, selanjutnya memecah dengan rinci menjadi unsur inti protein berupa monomer-monomer dan asam-asam amino bebas, yang sangat bermanfaat untuk perbaikan status nutrisional ikan. Bakteri probiotik juga mampu menghasilkan enzim lipase yang memicu produksi dan asimilasi asam-asam lemak esensial, sehingga menghasilkan pertumbuhan dan imunitas ikan gabus yang lebih tinggi. Asam-asam lemak esensial tidak hanya menjadi booster bagi sistem imun, tetapi juga memacu pertumbuhan (Sharma et al., 2009). Hidrolisis enzimatik bakterial menghasilkan peningkatan pertumbuhan ikan, menunjukkan ketersediaan biologik protein dan lemak yang meningkat. Amilase dan lipase merupakan enzim-enzim utama yang terkait dengan pemecahan karbohidrat dan lemak. Aktivitas amilase, protease dan lipase lebih tinggi pada ikan yang diberi pakan mengandung prebiotik dibanding kontrol. Aktivitas enzim amilase, protease dan lipase pada perlakuan prebiotik sebagian adalah hasil stimulasi oleh probiotik, dan bersama endoenzim bersinergi memperbaiki efisiensi kecernaan dan pemanfaatan nutrien, sehingga menghasilkan performa pertumbuhan yang baik (Djauhari et al., 2017).

Secara alami, prebiotik berpotensi merangsang sistem imun seluler melalui mekanisme aksi tidak langsung yaitu diawali dari keterlibatannya dalam merangsang pertumbuhan mikroflora menguntungkan seperti bakteri asam laktat dan Bacillus spp. (Zhang et al., 2011; Sang et al., 2011). Adanya peningkatan pertumbuhan dan diversitas mikroflora 
menguntungkan tersebut berdampak sinergis pada fermentasi oligosakarida tidak tercerna, surplus cadangan energi, sintesis vitamin B dan K, produksi SCFA, perbaikan struktur dan fungsi saluran pencernaan, reduksi kolesterol dan stimulasi sistem imun lokal (GALT = gastrointestinal associated lymphoid tissue), dimana sekitar $60 \%$ dari total limfosit yang bekerja dalam sistem imun ikan difasilitasi oleh GALT, yang mengandung lamina propria dan limfosit intraepitelium (lijima et al., 2001; Penders et al., 2006; Shadid et al., 2007).

\section{KESIMPUAN DAN SARAN}

\section{Kesimpulan}

Ikan gabus yang mengkonsumsi pakan berupa pasta jeroan patin menghasilkan tingkat kelangsungan hidup, laju pertumbuhan harian dan tingkat pertambahan bobot tubuh lebih baik.

\section{DAFTAR PUSTAKA}

Aquacop G, Cuzon Chou R, Fuchs J. 1989. Nutrition of the seabass (Lates calcarifer). Adv. Trop. Aquacult. Tahiti 9, 757-763.

Azza MM, Abd-El Rahman. 2009. Antagonism of Aeromonas hydrophila by propolis and its effect on performance of Nile tilapia, Oreochromis niloticus. Fish and Shellfish Imunology. 27: 454-459.

Bell JG, McGhee F, Campbell PJ, Sargent JR. 2003. Rapeseed oil as an alternative to marine fish oil in diets of post smolt Atlantic salmon (Salmo salar): changes in flesh fatty acid composition effectiveness of subsequent fish oil "wash out". Aquaculture, 218:515528.

Cremer MC, Jian Z, Lan HP. 2001a. Cage Production of Red Drum Weaned fromTrash Fish to Extruded Feed at Sub-Market Size. Results of ASA/China FeedingTrial 35-01-127. American Soybean Association.

Cremer MC, Jian Z, Lan HP. 2001b. Cage Production of Japanese Sea Bass Weaned from Trash Fish to Extruded Feed at Sub-Market Size. Results of ASA/China Feeding Trial 35-01128. American Soybean Association.

Curnow J, King J, Partridge G, Kolkovski S. 2006. Effects of two commercial microdiets on growth and survival of barramundi (Lates calcarifer Bloch) larvae within various early weaning protocols. Aquaculture Nutrition 12, 247-255. https://doi.org/10.1111/j.1365-2095.2006.00399.x.

Dimitroglou A, Merrifield DL, Spring P, Sweetman J, Moate R, Davies SJ. 2010. Effects of mannan oligosaccharide (MOS) supplementation on growth performance, feed utilisation, intestinal histology and gut microbiota of gilthead sea bream (Sparus aurata). Aquaculture 300:182-188.

Djauhari R, Widanarni, Sukenda, Suprayudi MA, Zairin M. 2017. Growth performance and health status of common carp (Cyprinus carpio) supplemented with prebitoic from sweet potato (Ipomoea batatas L.) extract. Pakistan Journal of Nutrition. 16: 155-163.

El-Asely AM, Abbass AA, Austin B. 2014. Honey bee pollen improves growth, immunity and protection of Nile tilapia (Oreochromis niloticus) against infection with Aeromonas hydrophila. Fish and Shellfish Immunology. 40: 500-506. 
Fuandila NN, Widanarni, Yuhana M. 2019. Growth performance and immune response of prebiotic honey fed pacific white shrimp Litopenaeus vannamei to Vibrio parahaemolyticus infection. https://doi.org/10.1080/10454438.2019.1615593

Gibson GR, Roberfroid MB. 1995. Dietary modulation of the human colon microbiota: introducing the concept of prebiotics. Journal of Nutrition 125:1401-1412.

Hepher B. 1988. Nutrition of Pond Fishes. Cambridge University Press. Cambridges, New York. $388 \mathrm{pp}$.

Hidayati D, Abdulgani N, Ashuri NM, Sa'adah NN, Lukitasari M. 2017. The influence of snakehead (Channa striata) fish extract to increase hyperglycemic mice fertility based on spermatogenic cell composition, in: AIP Conference Proceedings. AIP Publishing, p. 20015. https://doi.org/10.1063/1.4985406.

Hoffmann K. 2012. Functional aqua feeds: Dietary supplements pledge the breakthrough. http://en.engormix.com/MA-aquaculture/articles/functionalaqua-feeds-dietary2397/p0.htm.

lijima H, Takahashi I, Kiyono H. 2001. Mucosal immune network in the gut for the control of infectious diseases. Reviews in Medical Virology 11:117-133.

Jusadi D, Probosasongko AM, I Mokoginta. 2003. Pengaruh kadar silase jeroan ikan patin yang berbeda dalam pakan terhadap pertumbuhan ikan patin Pangasius hypophthalmus ukuran sejari. Prosiding Semi Loka "Aplikasi Teknologi Pakan dan Peranannya bagi Perkembangan Usaha Perikanan Budidaya. Pusat Riset Perikanan Budidaya. DKP. Bogor. 9 September 2003.

Karimah U, Anggowo YN, Falah S, Suryani. 2011. Isolasi oligosakarida madu lokal dan analisis aktivitas prebiotiknya. Jurnal Gizi dan Pangan. 6: 217-224.

Kenfack CHM, Ngoufack FZ, Kaktcham PM, Wang YR, Zhu T, Yin L. 2018. Safety and Antioxidant Properties of Five Probiotic Lactobacillus plantarum Strains Isolated from the Digestive Tract of Honey Bees. American Journal of Microbiological Research, Vol.6, No.1, 1-8. DOI:10.12691/ajmr-6-1-1.

Kordi KMGH. 2013. Farm Big Book - Budidaya Ikan Konsumsi di Air Tawar. Yogyakarta: Lily Publisher.

Kusuma MS. 2017. Kelangsungan hidup dan pertumbuhan benih ikan gabus (Channa striata) yang diberi ikan rucah berbeda sebagai pakan, Skripsi. Program Studi Budidaya Perairan Fakultas Pertanian Universitas Sriwijaya.

Mei G-Y, Carey CM, Tosh S, Kostrzynska M. 2011. Utilization of different types of dietary fibers by potential probiotics. Canadian Journal of Microbiology 57:857-865.

Mustafa A, Widodo MA, Kristianto Y. 2012. Albumin and zinc content of snakehead fish (Channa striata) extract and its role in health. IEESE International Journal of Science and Technology 1, 1.

Penders J, Thijs C, Vink C, Stelma F, Snijders B, Kummeling I. 2006. Factors influencing the composition of the intestinal microbiota in early infancy. Pediatrics 118:511-521.

Rachmansyah U, Palinggi NN, Williams K. 2009. Formulated feed for tiger grouper grow-out. Aquacul. Asia Mag., 30-35.

Rahmadya ND, Budiardi T, Saputra A. 2015. Pengendalian Kanibalisme Pada Pemeliharaan Benih Ikan Gabus (Channa striata) Dengan Padat Tebar Yang Berbeda Dalam Sistem Resirkulasi. Skripsi. Institut Pertanian Bogor. Bogor. Indonesia.

Salze G, McLean E, Schwarz MH, Craig SR. 2008. Dietary mannan oligosaccharide enhances salinity tolerance and gut development of larval cobia. Aquaculture 274:148-152. 
Sang HM, Fotedar R, Filer K. 2011. Effects of dietary mannan oligosaccharide on the survival, growth, immunity and digestive enzyme activity of freshwater crayfish, Cherax destructor Clark (1936). Aquaculture Nutrition 17:629-635.

Sanz ML, Polemis N, Morales V, Corzo N, Drakoularakou A, Gibson GR, Rastall RA. 2005. In vitro investigation into potential prebiotic activity of honey oligosaccharides. Journal of Agriculture and Food Chemistry, 53:2914-2921.

Saputra MB, Sasanti AD, Yulisman. 2019. Pengaruh perbedaan jenis pakan terhadap kandungan albumin dan kelangsungan hidup ikan gabus (Channa striata). In: Herlinda S et al. (Eds.), Prosiding Seminar Nasional Lahan Suboptimal 2018, Palembang 18-19 Oktober 2018. pp. 394-401. Palembang: Unsri Press.

Setiawati M, Nuraeni C, Jusadi D. 2007. Penggunaan Lemak Patin Dalam Pakan Ikan Nila (Oreochromis niloticus) Utilization of Catfish Body Fat in the Diet of Tilapia (Oreochromis niloticus). Jurnal Akuakultur Indonesia, 6(1): 89-95.

Shadid R, Haarman M, Knol J, Theis W, Beermann C, Rjosk-Dendorfer D. 2007. Effects of galactooligosaccharide and long-chain fructooligosaccharide supplementation during pregnancy on maternal and neonatal microbiota and immunity-a randomized, doubleblind, placebo-controlled study. American Journal of Clinical Nutrition 86:1426-1437.

Sharma P, Kumar V, Sinha AK, Ranjan J, Kithsiri HMP, Venkateshwarlu G. 2009. Comparative fatty acid profiles of wild and farmed tropical freshwater fish rohu (Labeo rohita). Fish Physiol Biochem 5:229-239.

Siburian ALM, Gunawan I, Djauhari R. 2020. Rasio kalsium fosfor, glukosa darah dan kinerja pertumbuhan ikan betok (Anabas testudineus) yang diberi prebiotik inulin. Jurnal IImu Hewani Tropika, 9(1): 1-7.

Silalahi H, Djauhari R, Monalisa SS. 2021. Growth performance of tambaqui (Colossoma macropomum supplemented with honey prebiotic in stagnant peat ponds. IOP Conf. Series: Earth and Environmental Science 679 (2021) 012007. doi:10.1088/1755-1315/679/1/012007

Solis de los Santos F, Farnell MB, Téllez G, Balog JM, Anthony NB, TorresRodriguez A, Higgins $S$, Hargis BM, Donoghue AM. 2005. Effect of prebiotic on gut development and ascites incidence of broilers reared in a hypoxic environment. Poultry Science, 84:1092-1100.

Song X, Xu J, Wang T, Liu F. 2010. Traditional Chinese medicine decoction enhances growth performance and intestinal glucose absorption in heat stressed pigs by up-regulating the expressions of SGLT1 and GLUT2 mRNA. Livestock Science, 128(1-3):75-81.

Teitelbaum JE, Walker WA. 2002. Nutritional impact of pre- and probiotics as protective gastrointestinal organisms. Annual Review of Nutrition 22, 107-138.

Vulevic J, Rastall RA, Gibson GR. 2004. Developing a quantitative approach for determining the in vitro prebiotic potential of dietary oligosaccharides. FEMS Microbiology Letters 236, 153-159.

Wicaksono YP, Shafruddin D, Saputra A. 2019. Pengendalian Kanibalisme Benih Ikan Gabus Channa striata Dengan Pemberian Triptofan. Skripsi. Institut Pertanian Bogor. Bogor. Indonesia.

Widodo P, Mudjiutami E, Firdausia, Tulus. 2014. Potensi dan prospek budidaya ikan gabus (Channa striata Bloch 1793) sebagai altenatif usaha dalam mendukung ketahanan pangan dan produksi perikanan budidaya di wilayah Kalimantan. Prosiding Seminar Perikanan Budidaya untuk Bisnis dan Ketahanan Pangan. Bogor : 26-29 Agustus 2014. Woods MN, Gorbach SL. 2001. Influences of fibers on the ecology of the intestinal flora. Pages 257-270 in G. A. Spiller editor. Handbook of dietary fiber in human nutrition. 
Zhang Q, Tan B, Mai K, Zhang W, Ma H, Ai Q, Wang X, Liufu Z. 2011. Dietary administration of Bacillus ( $B$. licheniformis and $B$. subtilis) and isomalto oligosaccharide influences the intestinal microflora, immunological parameters and resistance against Vibrio alginolyticus in shrimp, Penaeus japonicus (Decapoda: Penaeidae). Aquac Res 42:943952. 